\author{
服部 真一 $*$ ·大川 智船 $* *$ · 木本 美知子 $* * *$ ・樋口 大輔 $* * *$ 平山 大輔 $* * * *$ \\ 三重大学教育学部附属小学校 * 株式会社自然産業研究所 ** 三重県農林水産部 $* * *$ \\ 三重大学教育学部 $* * *$
}

\title{
Forest Environmental Education in an Elementary School Using a Supplementary Textbook
}

\author{
Shinichi HATTORI *, Chifune OKAWA **, Michiko KIMOTO ***, Daisuke HIGUCHI ***, \\ Daisuke HIRAYAMA \\ Elementary School Attached to Faculty of Education, Mie University * \\ Research Institute for Natural Capital Co., Ltd ** \\ Department of Agriculture, Forestry and Fisheries, Mie Prefectural Government *** \\ Faculty of Education, Mie University **** \\ (受理日 2018 年 6 月 4 日)
}

\section{Iはじめに}

持続可能な社会の構築に向けて、近年、森林の生態系機 能や林業抢よび木材利用の意義についての理解が進むよ うな取り組みが期待されており、そのために、 ESD (Education for Sustainable Development) の視点に基づ く森林環境教育の重要性が指摘されている（林野庁 2016)。ESDの視点から森林環境教育を推進するにあた り、子どもが森林に関心を持ち、森林の多面的機能やその 保全の重要性を正しく理解できるようになるための最初 のステップとして、小学校での取り組みが重要であると 考えられるが、現実には、十分な取り組みは少なく、小学 校での森林環境教育の推進には困難な点が多い。例えば、 2012年度に三重県で実施された、小学校での森林環境教 育に関するアンケート調查結果（調查対象 395 校、回答 290 校、回収率 $73 \%$ ）によると、森林に関する体験活動 (キャンプや自然観察・自然遊びも含めた広い意味でのも の)を全く行っていないと回答した学校は 75 校 $(26 \%)$ あ り、その抒もな理由としては、時間がない、指導者・講師が いない、イールドがないといった回答が上位を占めた。 また、全国的にみても、時間や予算・指導者の確保の面で の制約がある状況が指摘されている(堀田ほか 2007)。こ のような小学校における森林環境教育の扔もな課題を整 理すると、以下の三つにまとめられる。

1 ) 教師は一般に森林の専門家ではなく、何をどのよう に教えるかについて、学校側にノウハウが少ないこと。特 に、森林環境教育の内容は、理科や社会科といった複数の
教科に含まれる（あるいはどの教科にも含まれない）ため、 教科横断的、学際的な視点をもった取り組みが求められる。

2 ）林業の現場などでの体験学習は有効であるには違 いないが、費用や林業地へのアクセスの問題から、実施可 能な学校は一部に限られること。

3 ) 教師にとって、教科指導やその他の業務があるなか で、森林環境教育の優先順位は低くならざるを得ず、学校 が森林環境教育にかけることのできる時間は必然的に限 られること。すなわち、一回限りのイベント的な体験学習と しては実施することができても、継続的には取り組み難い。 このように、その重要性は認識されつつも実施の上で ハードルが高いのが実情であり、学校での森林環境教育の 推進には、これらを克服する授業展開例の具体化や教材等 の開発による学校教員への支援が不可欠となっている。

以上のような背景のもとで、三重県では、2014年に、 小学校での副読本「三重の森林とわたしたちのくらし」を 発行した (三重県農林水産部 2014)。これは抢もに小学校 第5 学年社会科の単元「森林資源の働き」における活用を 狙いとした副読本である。特徴として、森林の多面的機能 および循環型社会の重要性についての解説だけでなく、 校庭の樹木を使った体験型のワークや、子どもたちに とって身近な県内各地の森林と人の関わりの事例が多数 揭載されている(表1)。なお、この副読本の電子ファイル (PDF) は三重県庁のウェブサイトでの閲覧拉よびダウ ンロードが可能である。

本研究は、この副読本を活用した森林環境教育を小学 校で実践し、その有效性を検討することを目的とした。実

問い合わせ先 テ514-8507 三重県津市栗真町屋町 1577 三重大学教育学部 平山大輔 E-mail: daisuke@edu.mie-u.ac.jp 
践に際しては、上述の問題点を克服するために、理科、社 会科などの複数の教科の中で年間を通して実施するこ ととした。森林環境教育は単一の教科の内容には収まら ないが、様々な教科内の関連する項目を活用することに より、日常の個々の教科の学習を通じた森林環境教育の 推進が可能になると考えたためである。このことは、別 の観点からも重要な意義をもつ。森林環境教育において は、森林の多面的機能等についての知識の習得に加え、 森林と人間の関わりについての問題解決に向かう態度 を養うことが重要であるが、そのような態度の涵養は、 一時限あるいは一単元といった比較的短い時間では難 しい。すなわち、副読本により教師にとっての授業のし やすさを担保し、また、教科横断的で継続的な学びとす ることで、より深い森林環境教育とすることができると 考えられる。

\section{表 1 三重県の副読本「三重の森林とわたしたちのくらし」} の内容.

\begin{tabular}{|c|c|c|}
\hline テーマ & ページ数 & 内容 \\
\hline もしも森がなかったら？ & 2 & 森林の多面的機能の解説 \\
\hline $\begin{array}{l}\text { 木を切ることは自然破 } \\
\text { 壞？ }\end{array}$ & 1 & $\begin{array}{l}\text { 人工林に大切な「植える」· } \\
\text { 「育てる」・「収穫する」の循 } \\
\text { 環の解説 }\end{array}$ \\
\hline $\begin{array}{l}\text { 三重県の木はどこに使わ } \\
\text { れているの? }\end{array}$ & 1 & $\begin{array}{l}\text { 県産材の身近な利用事例の } \\
\text { 解説 }\end{array}$ \\
\hline $\begin{array}{l}\text { 森のお仕事ってどんなも } \\
\text { の? }\end{array}$ & 1 & 森に関わる職業の紹介 \\
\hline 校庭の木を調べよう & 1 & $\begin{array}{l}\text { 校庭の樹木の二酸化炭素固 } \\
\text { 定量を調べるワークシート }\end{array}$ \\
\hline $\begin{array}{l}\text { 三重県の森にはどんな特 } \\
\text { 徵があるの? }\end{array}$ & 1 & $\begin{array}{l}\text { 天然林も含めた県内の森林 } \\
\text { の特徵の地形・地理的な側 } \\
\text { 面からの解説 }\end{array}$ \\
\hline 地域と森のつながり & 7 & $\begin{array}{l}\text { 県内各地で林業・森林保全· } \\
\text { 県産材の普及・啓発等に関 } \\
\text { わる人・団体の紹介 }\end{array}$ \\
\hline
\end{tabular}

\section{II 方法}

\section{1 授業計画の作成}

三重県の副読本では、森林の多面的機能を次の 9 項目 に整理している；1) 快適な環境をつくる、2)二酸化炭 素をたくわえる、3)きれいな空気をつくる、4)木材を 生み出す、5)水をたくわえる、6)風や砂を防ぐ、7)川 や海を豊かにする、8)動植物のすみかとなる、9)土を 支える(三重県農林水産部 2014)。

既に述べたように、この副読本は社会科の単元「森林 資源の働き」(5年)に対応するものであるが、第 5 学年社 会科単元を起点として様々な教科・単元へ展開すること で学びを深めることができると考えられる。そこで、本 実践は第 6 学年の児童を対象とすることとし、まず、第 6 学年の各教科内容と照合して、上記の 9 項目の森林の機 能に関連する内容を抽出した。その結果、9つのうち 5 つ の森林機能については、国語、理科、社会、図画工作の内 容への位置づけが可能であることが分かった（表2）。残
りの4つを総合的な学習に位置づけることで、森林機能 の9項目の学習が可能な授業計画を、教師自身が作成す ることができた。動植物のすみかとなる森林機能につい ては、理科と国語の $2 つ の$ 教科で計画を立てたため、総授 業テーマ数は 10 となった(表 2$)$ 。

表2 副読本の森林機能と対応させた授業計画.

\begin{tabular}{|c|c|c|c|}
\hline 森林機能 & 教科 & 授業テーマ (小単元・題材 $)$ & 時数 \\
\hline $\begin{array}{l}\text { 動植物のすみか } \\
\text { となる }\end{array}$ & 理科 & $\begin{array}{l}\text { かれ葉を食べるダンゴムシ（生物 } \\
\text { どうしの関わり） }\end{array}$ & 1 \\
\hline $\begin{array}{l}\text { きれいな空気を } \\
\text { つくる }\end{array}$ & 理科 & $\begin{array}{l}\text { 植物が出し入れする気体（生物ど } \\
\text { うしの関わり） }\end{array}$ & 1 \\
\hline $\begin{array}{l}\text { 川や海を豊かに } \\
\text { する }\end{array}$ & 理科 & $\begin{array}{l}\text { アコヤガイの体のつくりと養殖真 } \\
\text { 珠 (体のつくりとはたらき・生物 } \\
\text { どうしの関わり) }\end{array}$ & 2 \\
\hline 木材を生み出す & $\begin{array}{l}\text { 図工 } \\
\cdot \\
\text { 総合 }\end{array}$ & $\begin{array}{l}\text { テープカッターを作ろう（図工； } \\
\text { 板から作ろう)・木で作られた身 } \\
\text { の回りの物 (総合) }\end{array}$ & 6 \\
\hline $\begin{array}{l}\text { 二酸化炭素を蓄 } \\
\text { える }\end{array}$ & 理科 & $\begin{array}{l}\text { 校庭の木は二酸化炭素のタンクだ } \\
\text { (生物どうしの関わり) }\end{array}$ & 1 \\
\hline $\begin{array}{l}\text { 水を蓄える・土 } \\
\text { を支える }\end{array}$ & 総合 & 植物が支える水と土 & 1 \\
\hline $\begin{array}{l}\text { 動植物のすみか } \\
\text { となる }\end{array}$ & 国語 & 森へ（星野道夫著 森へ） & 1 \\
\hline 木材を生み出す & 社会 & $\begin{array}{l}\text { ブラジル連邦共和国（世界のなか } \\
\text { の日本とわたしたち） }\end{array}$ & 1 \\
\hline $\begin{array}{l}\text { 快適な環境をつ } \\
\text { くる }\end{array}$ & 総合 & 森は涼しい（野外活動） & 2 \\
\hline 風や砂を防ぐ & 総合 & 海岸林を見てみよう（野外活動） & 2 \\
\hline
\end{tabular}

\section{2 「森のノート」の配布}

今回の実践は、複数の教科のなかでの長期にわたる学 習となるため、児童にとっては習得した知見が細切れに なり、俯瞰的に学びを振り返ることが難しくなる可能性 が考えられた。そのため、実践開始前に、児童には各自 1 冊のノートを配布した。これを「森のノート」として、学 習した内容や感じたことを記録させることで、得た知識 の整理・蓄積と深い定着を図った。すなわち、「森のノー 卜」は、本実践を単に各教科の一部分に森林環境教育の 要素を組み込んだ散発的な学習ではなく、教科横断的な

一貫した学習とする上で鍵となると考えた。

具体的には、教科のノートとは別に、それぞれの授業 の中で一定の時間を設け、森について学習したことのま とめを「森のノート」に記録させた。また、適宜、授業の中 で前回行った学習を振り返るためにも使用した。調べ学 習の際には、疑問に思ったこと、調べたこと等をこの ノートに記述させた。授業ごとに提出させ、教師が適宜 コメントを付して返却した。一連の実践が終わった後に は、実践全体を振り返って、感想を記録させた。

\section{3 森林環境教育の実践}

2015 年 10 月から 2016 年 2 月にかけて、津市の三重大学 教育学部附属小学校 6 年生 33 名を対象として、考案した 授業(表2)の実践を行った。授業は、基本的に、小学校教 
員である筆頭著者が行ったが、「校庭の木は二酸化炭素 のタンクだ」は大学教員である共著者が行った。

4 つの教科 (国語、理科、社会、図画工作) および総合的 な学習の時間を用いて計画した10の授業のうち、8つを 実施することができた。しかし、森林機能「快適な環境を

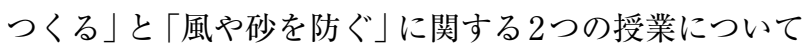
は、野外活動として学校外での授業を計画したが、移動 手段を確保できなかったことから、今回の実践において は実施できなかった。以下に、実施できたそれぞれの授 業の概要を記す。

1)「かれ葉を食べるダンゴムシ」

2015 年 10 月 5 日の 5 時限目に、理科の単元「生物どうし の関わり」における「食べ物を通した生物どうしの関わ り」の学習を、動植物のすみかとなる森林機能と関連づ けて行った。校庭の中の比較的樹木が多数植えられてい る場所で、班ごとにサクラ(ソメイヨシノ)の枯れ葉 2 枚 とダンゴムシ 20 匹を採集し湿らせた滤紙を敷いた飼育 ケースに入れさせた。飼育ケースを教室のロッカー内に 置き、翌日、全員に観察させた。全ての班で、ダンゴムシ により枯れ葉が食べられていることを確認し、ダンゴム シの糞があることも確かめさせた。この糞については、 より小さな生物の食物となり、少しずつ土壤が形成され ていくことを映像教材と資料から理解させた。また、森 林ではダンゴムシ以外にも枯れ葉などを食べる土壌動 物の種類が多いことなどの説明も行い、副読本の記述の 通り、森林が多様な動植物のすみかとなっていることを 理解させた。以上のように、食物を通じた生物のつなが りを学ぶというこの小単元の目的を達成すると同時に 森林機能についての学習を実施した。

\section{2)「植物が出し入れする気体」}

2015年 10 月 6 日の 4 時限目に、理科の単元「生物どうし の関わり」に抏ける「空気を通した生物どうしの関わり」 の学習を、きれいな空気をつくる森林機能と関連づけて 行った。教科書 (大日本図書; 新版 たのしい理科 6 年) (有 馬ほか 2015) に掲載されている、植物が出し入れする気 体を調べる実験方法に従い、以下のように実施した。ま ず、班ごとに校庭で野草と樹木を選び、葉が多数ついた 枝にビニール袋をかぶせ、空気が出入りしないように袋 の口をモールで縛らせた。次に、ストローを用いて袋内 に呼気を吹き込ませた上で酸素と二酸化炭素の濃度を 気体検知管で測定させた。1時間日光に当てた後に再び 酸素と二酸化炭素の濃度を測定させた。その結果、全て の班で、酸素濃度が増え、二酸化炭素濃度が減ったこと を確認した。この実験を通して、植物には日光が当たる と二酸化炭素を吸収して酸素を放出する働きがあるこ と、また、森林の樹木も同様であることを理解させた。た だし、植物も動物と同じように常に呼吸をしている。ま た、森林の構成要素には樹木だけでなく動物も含まれ、 その呼吸により二酸化炭素が放出される。さらに、枯死
した樹木の分解等によっても二酸化炭素は放出される。 これらの収支の結果として森林全体でみた場合の気体 濃度の変化は決まるが、この授業内ではその解説は行わ ず、樹木が日光のもとで二酸化炭素を吸収して酸素を放 出する働きにより、森林はきれいな空気をつくるという 説明に留めた。

3）「アコヤガイの体のつくりと養殖真珠」

2015年 12 月 15 日の 3-4 時限目に、理科の単元「体のつ くりとはたらき」と関連させて、人以外の動物の体のつく りを知ることをねらいとしてアコヤガイの体のつくりの 学習を行い、その中で、川や海を豊かにする森林機能の学 習も合わせて行った。教科書 (大日本図書; 新版たのしい 理科 6 年）（有馬ほか 2015）では、単元「生物どうしのか かわり」の中で、豊かな森が川や海を豊かにするという話 題をコラムで取り上げており、これも活用して実施した。 アコヤガイの体のつくりを解剖により観察し、貝にも人 と同じょうに臓器があることを理解させた。この観察の 後、アコヤガイの体から真珠を取り出させ、真珠の養殖に ついて、産地は三重県の英盧湾であり、海中の栄養の豊か さには川の上流の森林が大切な役割を果たしていること 等を解説した。副読本では、三重県の南勢地域で、カキ養 殖やアマモ場の保全を通して海と森のつながりを大切に する取り組みが行われていることも詳しく紹介されてお り、これらの事例も合わせて紹介することで、森林機能と 漁業に繋がりがあることを理解させた。

4)「テープカッターを作ろう」「木で作られた身の回り の物」

2016 年 1 月 20 日から 2 月 3 日にかけて、6時限分の授 業 (図画工作 5 時限、総合 1 時限)に扔いて、木材を生み出 す森林機能と関連づけた学習を行った。まず、図画工作 の題材「板から作らう」に扔いて、木を材料としたテープ カッター作りに取り組ませた。その後、総合的な学習の 時間において、完成したテープカッターをもとに、木で 作られた身の回りの物についての授業を行った。テープ カッターに用いた木も森林で育てられたものであるこ と、木を切り出し、加工して木材としたものを私たちは 生活の中で利用していること、また、副読本にも記され ている通り、身の回りには木で作られたものがたくさん あり、私たちの生活に役立っていることなどを理解させ た。さらに、木材として外国のものを多く利用している ことも解説した。ただし、木材輸入についてはのちの社 会科の授業で扱うため、この授業においては簡単に触れ るに留めた。

\section{5）「校庭の木は二酸化炭素のタンクだ」}

2016 年 2 月 23 日の 3 時限目に、理科の単元「生物どうし の関わり」において、二酸化炭素を蓄える森林機能と関 連づけて植物の光合成の授業を行った。この授業のねら いは、樹木が二酸化炭素を蓄える働き（二酸化炭素固定 機能）をもつことを学ぶことと、木でできたものをたく 
さんかつ長く使うことの意義を学ぶこととし、副読本に 揭載されている体験型ワークを活用した。これは、樹木 の幹周囲の長さと二酸化炭素固定量を対応させた早見 表をもとに、児童自身が樹木の二酸化炭素固定量を求 め、一年間の生活から排出される二酸化炭素量と比較す るといった内容のワークである。なお、上記の実践 2 の 通り、この授業までに児童は既に植物が光の存在下で二 酸化炭素を吸収する働きをもつことを学習していた。

授業の展開部では、班ごとに校庭で樹木を選択させ、巻 尺を用いて幹の周囲を測定させた。早見表を利用して、測 定した周囲長に対応する二酸化炭素固定量を読み取ら せ、その樹木が体内に蓄積した二酸化炭素量を求めさせ た。また、年間に一人の人間の生活から排出される二酸 化炭素量 $(2,300 \mathrm{~kg})$ と求めた二酸化炭素固定量を比較す ることで、自分たちの一年間の暮らしを支えるためには 測定した樹木が何本必要となるのかを考えさせた。

6）「植物が支える水と土」

2016 年 2 月 25 日の 5 時限目に、総合的な学習の時間に おいて、森林のもつ水を蓄える機能と土を支える機能を 学ぶことをねらいとした授業を行った。まず、植物の根 が実際に土を支える働きをもつことを、実験を通して確 認した。班ごとに、容量 $350 \mathrm{~mL}$ のビニールポットで園芸 用土に植えて育てたビワの苗木、及び、同サイズのビ ニールポットで園芸用土のみを入れて押し固めたもの を用意した。なお、このビワの苗木は、一年前に給食で出 されたビワから種子を取り出し、児童が発芽させて栽培 していたものである。これら二つをそれぞれビニール ポットからトレーに出し、ビワの根が張り巡らされてい る土の塊を「ビワ山」土だけの塊を「土山」とした。ビワ

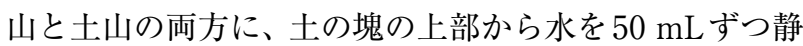
かに注ぎ、変化を観察した。土山の方は、水を注ぐに連れ て少しずつ塊状の土が崩れていき、 $450 \mathrm{~mL}$ の水を注い だ時点で全ての班の土の塊はトレー内に平らに広がっ た状態となった。一方、ビワ山の方は、程度の差はあるも のの、計 $2500 \mathrm{~mL}$ の水を注いでも、どの班でも土の塊が 維持されていた。この観察実験を通して、根には土を支 える働きがあることを確認した。さらに、副読本に記さ れている通り、実際の森林では、多くの樹木が根を張り 巡らせていることで土を支えていること、人工林の放棄 や過剩な伐採などで森林が荒廃して張り巡らされる根 の量が減るなどすると、大雨などの際に大規模な地滑り や水害が生じやすくなることを解説し、森林には土を支 え、水を蓄える働きがあることを理解させた。

\section{7)「森へ」}

2016 年 2 月 25 日の 4 時限目に、国語の授業において、教 科書 (光村図書 ; 国語六)（甲斐ほか 2015）に掲載されて いる星野道夫著「森へ」を使用し、動植物のすみかとして の森林の学習を行った。なお、既に 1 学期に国語の授業と して 5 時間を「森へ」の学習に充てていた。本時では、「森
へ」の文章の中から、森林のはたらきや動植物のくらし が記述されている箇所を抽出させ、森林の中にはどのよ うな動植物のくらしが見られ、森林がどのように成り 立っているのかを考えさせた。その際、作者の森林に対 する気持ちや感想の記述ではなく、具体的に森林のはた らきや動植物のくらしが記述されていると判断できる 箇所を選び出してノートに書かせた。监童は、ハクトウ ワシ・クロクマ・サケ・アカリス・コケ・キノコ・地衣類な ど森林には様々な生物が棲んでいること、クマの顀がキ ノコを育てること、トウヒの種子が倒木の栄養をもらい ながら膨大な時間をかけて大木へと成長していくこと などについて理解したことを発表した。

\section{8 ）「ブラジル連邦共和国}

2016 年 2 月 24 日の 5 時限目に、社会科の単元「世界のな かの日本とわたしたち」におけるブラジル連邦共和国を 題材とした授業のなかで、木材を生み出す森林機能と関 連づけた学習を行った。使用教科書 (日本文教出版; 小学 社会6年下）（井田ほか 2015）では、ブラジルのアマゾン 川流域の森林環境について学習する場面がある。この場 面に合わせて授業を実施した。教科書に沿って、ブラジ ルにおける森林伐採と森林減少、日本の外材輸入、日本 の人工林の荒廃などについて学習した後、さらに調べ学 習を行い、森林の保全に向けた課題などについて知った ことを全体の場で発表させた。副読本では、植える・育て る・収穫する・利用するといった緑の循環や、利用によっ て得られた収益の新たな森づくりへの活用などにより、 日本の人工林を荒廃させない仕組みの重要性にも触れ て扔り、それらを通して览童に日本の木材利用の意義を 伝えられるよう実践を進めた。

\section{4 有効性の検討}

一連の授業実践を全て終えた後 (2月 26 日) に、全児童 33名を対象にアンケート調査を実施した。質問項目は以 下の通りである。

1) 森は私たちの日常のくらしと深く関わっている。

2)木で作られたものを、たくさん、長く使うことが大 切だ。

3 )二酸化炭素はできるだけ空気中に出さない方が良 い。

回答には、とてもそう思う、そう思う、どちらでもな い、そう思わない、全くそう思わないから選択する方法 を用いた。これにより、実践後の児童の、森林と人間生活 の関連に関する概念的な理解（質問 1 および 2 ）と環境 配慮意識(質問 3 )を調べた。

また、「森のノート」に各自の感想を自由記述式で書か せた。ノートの回収後、児童のそれぞれの記述を「森林へ の関心の芽生え」、「森林機能の理解」「人間生活と森の かかわりへの気づき・理解」「意識の変化」「行動の変 化」の $5 つ$ の観点に分類し、どのような観点の記述が多い 
か、また、一人当たりの記述の観点数にどのような特徵 がみられるかについて分析した。

\section{III 結果と考察}

計画した10の授業のうち、既に述べた通り、野外活動

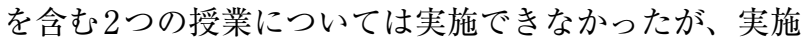
した8つの授業においては、計画通りに遂行することが できた。また、どの授業でも、児童が意欲的に取り組む姿 が見られた。

アンケート調査の結果、一部の授業に欠席した 2 名を 除く 31 名の児童からの回答を分析に供した。

森林と人間生活の関連に関する概念的な理解や環境配 慮意識については、いずれも高い結果が得られた。しかし、 今回の実践においては、実践前の段階での意識調査は行っ ていないため、このアンケート結果をもって今回の森林環 境教育の実践に高い効果があったか否かを判断すること はできない。今後、質問項目の検討も含めアンケートの実 施方法を改善して実践を積むことで有効な分析が可能と なると考えられるため、ここでは結果の記載に留めたい。

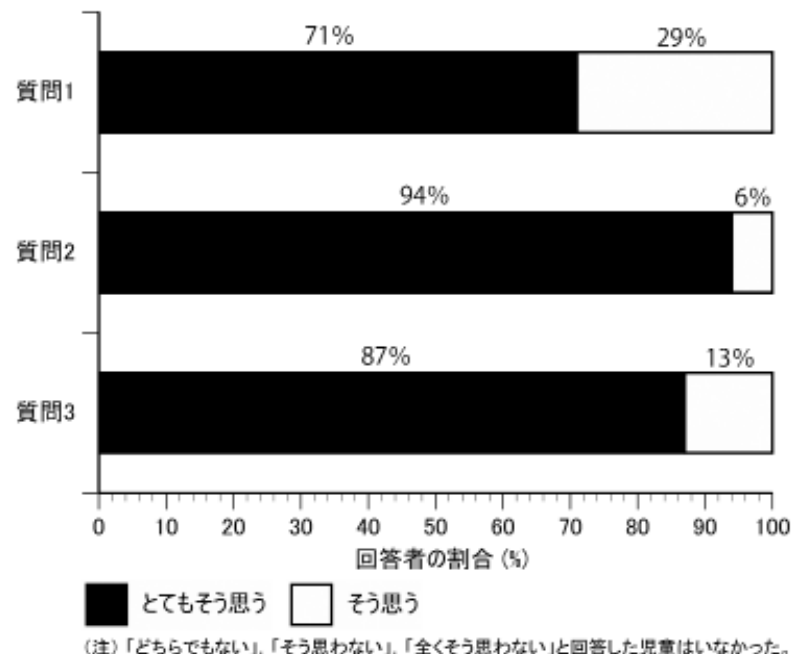

図 1 実践後のアンケートへの回答結果.

一方、「森のノート」の感想の記述からは、興味深い結果

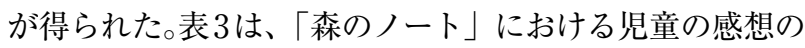
記述を観点ごとに整理したものである。「森林への関心の 芽生え」から「行動の変化」に向かって学びの梁さが媣くな るよう並べた。その結果、最も記述数が多かったのは「森林 機能の理解」に関するものであり、21名 $(68 \%)$ の児童が言 及していた。また、「意識の変化」に関する記述も多く、18 名 (58\%) の览童でみられた。览童個別にみると、「森林機

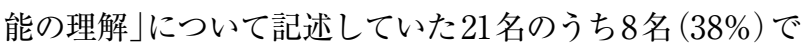
は、他の観点からの記述がひとつもなく、一人当たりの記 述観点数は 1.95 であったのに対し、「意識の変化」に関す る記述がみられた18名のうち、他の観点からの記述がひと つもなかったのは 2 名(11\%)に留まった。16名(89\%)では 他の観点からの記述もみられ、一人当たりの記述観点数は 2.39であった。特に、そのうち3名の児童では「行動の変化」
表3「森のノート」の児童の記述.

\begin{tabular}{|c|c|c|c|}
\hline & 記述例 & 記述の分類 & 人数 \\
\hline (1) & 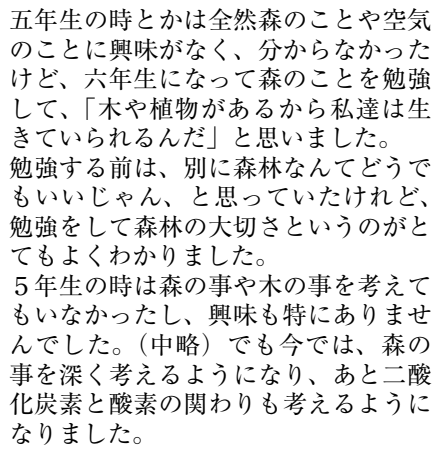 & $\begin{array}{c}\text { 森林への関心の } \\
\text { 芽生え }\end{array}$ & 5 名 \\
\hline
\end{tabular}

(1) 木は $\mathrm{CO}_{2}$ をたくさんたくわえること を初めて知りびっくりしました。

(2) 森は木や草などの植物だけでなく、動 物や鳥、昆虫など、多くの生き物のす みかとなり、そのくらしを支えている ことが分かった。

（3）森は川や海を豊かにすることもできる のでびっくりした。

(4) 台風とかがきてもあまり土砂崩れが起 きないのは木の根のはたらきだと知り 驚きました。

(1) あんまり人は自然と関わっていないと 思っていたが、この授業を学んでから は自然と関わり合って生きているとい うことが分かった。

(2) 家や田畑のまわりに植えられた木夕 は、風や砂から私たちのくらしや農作 物を守るはたらきもある。木は私たち のくらしに大きな影響をあたえている 事が私の一番の発見です。

(3) 人工林は適度に切られた方が林業やそ の土地のためになるとはまったく知ら なかった。

(1) 森の学習を通して、これから、木をリ サイクルしたり、たくさんそして長く 使ったり、三重の木を使ったりしょう と思いました。

(2) 本やざっしはふつうにすてるのではな く、はいひんかいしゅうにだしたりす るなどし、今自分にできることをしっ かりし、できるだけ二酸化炭素をださ ないようにしょうと思った。

(3) 森の中にはいろんな動植物がいるの で、森を大事にしたい。

(1) 森の学習をしているときに、新しく ベッドを買いました。家具屋さんへ行 くと、パイプベッドと木製のベッドが おいてありました。パイプベッドのほ うが安い值段だったけれど、木材製品 を長く使うことで $\mathrm{CO}_{2}$ を減らすこと ができると習ったばかりだったので木 製ベッドを買いました。そのベッドは 国産だったので日本の林業の役に立て たかなと思いました。買ったベッドを 長く使い $\mathrm{CO}_{2}$ を少しでも少なくでき るようにしたいなと思いました。

(2) 土曜日に木せいのいすを買いました。 プラのいすの方が安かったけど、森の 勉強をして見かたが変わったので木せ いを買った。

人間生活と森の かかわりへの気 10 名 づき・理解

意識の変化 18 名

（注）無回答およびー人による複数回答もあるため、回答 数の合計は調査対象人数（31名）と一致しない.

に関する記述もみられ、学習したことがその後の自らの生 活の中での選択に影響を与えていたことが分かった（表 3)。これらのことから、「意識の変化」について記述した児 童では、下位の「関心の芽生え」から上位の「行動の変化」ま 
でについての記述も比較的充実していることが分かる。

環境問題を背景とする環境教育では、問題を理解する ことおよび、その解決のための行動へとステップを進める ことが目的となるが、これは森林環境教育でも同様である （山本 2004、井上・大石 2014）。そのような視点からは、「森 のノート」に見られるこれら児童の行動に関する記述は、 今回の一連の実践が有意義であったことを示唆している。

今回の実践は三重県が発行した副読本を活用して行っ た。既に述べた通り、小学校教師は一般に森林の専門家で はないため、何をどのように教えるかについてのノウハ ウが学校現場にはほとんどない。そのような場合、外部講 師に依頼するなどして森林体験学習がなされることが多 いが、費用や時間等の問題がある（堀田ほか 2007）。その ため、実施可能な学校は一部に限られる上、実施したとし ても一回限りのイベント的な体験学習に終始してしま い、継続的には取り組み難い。さらに、森林の専門家が外 部講師として児童対象の森林体験活動を実施する場合で も、学校教員と専門家の間で何をねらいとするかの認識 の隔たりが生じる事例があることも報告されている（井 上·大石 2011、2014）。したがって、学校で森林環境教育を 推進するためには、堀田ほか $(2007)$ が指摘するように、教 師自らが指導者となることが求められる。本研究では、森 林機能および森林資源の循環の重要性等を分かりやすく 整理した副読本を利用し、それと関連した各教科内容を 抽出することにより、教師自身が森林環境教育の授業計 画を作成することができた。また、そのように各教科内容 と関連づけるとで、日常の教科指導の中で継続的に森 林環境教育を実施することが可能となることを実践によ り示すことができた。この意義は大きいと言えるだろう。

2015 年に三重県農林水産部が実施した副読本の使用 状況のアンケート調査 (調査対象 375 校、回答 243 校、回 収率65\%）によると、この副読本を授業で実際に使用し ていると回答した小学校は 177 校 $(73 \%)$ にのぼる（三重 県、未発表)。三重県では、この副読本の企画段階から、行 政・専門家・制作者が学校現場に寄り添う意図をもち、現 場でよく活用されるものにすることが強く意識されて いたが、制作時に目指した通り、この副読本は現場の教 師から一定の支持を得ていることが分かる。

また、さまざまな教科の授業のなかで森林環境教育を 行った今回の実践を通して、現在の各教科書の記述には 森林と関連する内容が随所に盛り込まれていることが分 かった。例えば、本実践でも「かれ葉を食べるダンゴムシ」 として活用した教科書 (大日本図書 ; 新版 たのしい理科 6 年）（有馬ほか 2015）の「食べ物を通した生物どうしの 関わり」内の「資料りかのたまてばこ」では、森林の地面 には森林で育った植物の落葉や落枝が多量にあり、これ らが林床に生息する小型動物に分解されることが写真と ともに紹介されており、また、その内容に続くコラム「発 展 ジャンプ」では、「豊かな森が川や海を豊かにする」と
して、森林の落葉・落枝を食べた小型動物の粪などが豊か な土壤を作り、その養分が少しずつ運ばれ、川や海に生息 する生物を育むことが紹介されている。このように、森林 そのものを学習する単元ではなくても、教科書には森林 環境教育と親和性の高いつくりとなっている部分もあ り、このような部分を活用することで、授業のなかで森林 についての理解をさらに深めることができるだろう。

以上のことから、副読本を活用し、第6学年の様々な教 科の授業と関連づけて実践した本研究の授業は、小学校 での森林環境教育として有意義であったと考えられる。

ただし、既に述べた通り、当初計画していた野外活動を 含む $2 つ の$ 受業については実施できなかった。森林環境 教育において、野外活動の持つ意義は大きい。今回企画し た一連の森林環境教育の有効性は、今後、野外活動を含 む全ての実践を行った上で検証する必要があるだろう。

\section{謝辞}

本研究の実施にあたり、授業実践にご協力いただいた三 重大学教育学部附属小学校の皆様に感謝申し上げます。

\section{引用文献}

有馬朗人 ほか 42 名, 2015 ,『新版 たのしい理科 6 年』, 大日本図書, 東京, $188 \mathrm{pp}$.

堀田紀文 - 広嶋卓也 - 坂上大翼 - 山本清龍 - 田中延亮 柴崎茂光, 2007, 「森林の多面的機能を題材とした森林 教育テキストの作成方針 一既存の森林教育テキストの 比較解析から一」,『日本森林学会誌』, 89: 374-382.

井田仁康 ほか 27 名, 2015, 『小学社会 6年下』（監修； 池野範男 - 的場正美 - 安野功), 日本文教出版, 大阪, 84pp.

井上真理子 - 大石康彦, 2011, 「学校と外部指導者が連携 して森林教育を行うための条件と課題」,『関東森林 研究』, 62: 49-52.

井上真理子 - 大石康彦, 2014,「森林教育に関する教育目 的の構築 一学校教育を中心とした分析をもとに一」, 『日本森林学会誌』, 96: 26-35.

甲斐睦朗 ほか 41 名, 2015, 『国語 六 創造』, 光村図書, 東京, 284pp.

三重県農林水産部, 2014, 『三重の森林とわたしたちのく らし』，三重県農林水産部，三重，14pp. http://www. pref.mie.lg.jp/common/content/000711584.pdf（2017 年 9 月 1 日アクセス)

林野庁, 2016, 森林 - 林業基本計画, http://www.rinya.maff. go.jp/j/kikaku/plan/pdf/160524_01kihonkeikaku.pdf (2017年 3 月 3 日アクセス)

山本信次, 2004, 「森林における総合的な学習とは何か 一林業関係者と教育関係者のより良い協働のために 一」, 全国林業改良普及協会編『森で学ぶ活動プログ ラム集 2』，全国林業改良普及協会, 東京, 14-20. 